\title{
The Interplay between Multilateral Regimes as the Relationship between Trade and Environmental Rules ${ }^{\#}$
}

\begin{abstract}
Jakub Krс̈*
The recent development of a discussion about the consequences of several measures adopted as a solution of the climate change problem for the multilateral trade system arose many interesting questions. One of them may be how the specific norms introduced under the climate change regime interfere with the multilateral trade system, respectively, if the different rules confirm or contradict each others. The relationship between the World Trade Organization (WTO) and the Kyoto Protocol ${ }^{1}$ seems to be an ideal example that could be used for an appropriate case study describing the linkage between the trade and environmental regimes. The theoretical approach suitable for this paper was found in the regime theory and its regime interplay analysis. The basic fact followed in the paper is that the international organization could extend the field of its operations to the areas where it was not originally intended to function and therefore could influence the other international organizations.

The major aim of this paper is to outline the interferences of two multilateral regimes, the world trade rules under the WTO system and the environmental norms established under the United Nations Framework Convention on Climate Change ${ }^{2}$ and the following Kyoto Protocol. It stresses the possible areas of conflicts as arose from the normative analyses of both international regimes. As the room for this paper is constrained, a set of limitation had to be respected. The trade regime was only generally described as it was established after the creation of the WTO in 1994. The simplification were made in respect to the number of players, as the developed countries were considered as a single actor, and to the climate change regime that could not be analyzed in more appropriate and detailed way.

In this paper, there are identified two different regimes. First one, the WTO system, involves several features that are very important for our regime interplay. The so called Dispute Settlement Mechanism represents probably the most important one, while the evolving negotiations within the Committee on Trade and Development rather stagnate. The relatively new regime under the Kyoto System is hard to evaluate due to the non-participation of many crucial countries. On the other hand, its provisions represent the only con-

\footnotetext{
Article has been worked out within the framework of the Czech Science Agency Project "Regionalism and multilateralism: foundations of the new world trade order?" No. 402/07/0253, and the Research Plan of the Faculty of International Relations "Governance in context of globalised economy and society" No MSM 6138439909. University of Economics, Prague, nám. W. Churchilla 4, 13067 Praha 3, Czech Republic; <jakub.krc@vse.cz>. Kyoto and entered into force in February 2005. environmental treaty produced at the United Nations Conference on Environment and Development (UNCED), held in Rio de Janeiro in 1992.
}

* Mgr. Ing. Jakub Krč - Ph.D. student, Department of World Economy, Faculty of International Relations,

1 The Kyoto Protocol was agreed on in December 1997 at the Third Conference of the Parties to the UNFCCC in

2 The United Nations Framework Convention on Climate Change (UNFCCC or FCCC) is an international
\end{abstract}


crete binding rules related to the Green House Gases (GHGs) ${ }^{3}$ emissions and therefore its impact should not be underestimated. The international regime is understood according to the standard definition (Krasner, 1983) as principles, norms and procedures in certain specific areas and it is important to mention that this paper consider the regime as interchangeable with the term institution.

\section{The interaction between international regimes - regime interplay}

For many years, the studies of the international regimes had been focused on two major questions. First, how the regimes and their appropriate international organizations were established and how they operate. The second question dealt with the problem of their effectiveness. Until recently, there was a lack of studies concerning the side effects of operations of international organizations. It may be assumed that the regimes were analyzed as if they had existed separately in isolation from others. The recent analysis count on the problem of the international regime interplay, but the conceptual work on their interaction are still in the beginning and have not come up with the encompassing conclusion.

Many of the papers that focused on the subject of regime interplay are centered on the inter-institutional conflicts that are somehow related to the political interests of developed, industrialized countries. The typical example is the relationship between the World Trade Organization and its international free trade regime and the Multilateral Environmental Agreements establishing the environmental regimes and possibly representing new trade barriers and restrictions. This could be called the negative framing of the interplay issue (Stokke, 2001), but the analysis of the subject show that the majority of cases include the positive impacts as well and the interaction between regimes can result also in synergies.

In regard to the problem of the regime interplay, many different expressions can be found in recent literature to describe the same topic. It can be analyzed as the institutional linkage, inter-linkage, interaction or interconnection, but all terms are understood in the same way, dealing with the same phenomena as here (Oberthür, 2003, pp. 104-116). The concept of the regime interplay describes the situation, where the rules, operations and the outcomes of one organization and its regime, in our case at the international level, are strongly affected by the other organization with a different regime. There have been many distinctions made on the basis of the form or the substance of the interplay of the regimes. For the purposes of this paper, the theoretical division of the regimes is not so important, but few remarks have to be mentioned.

The regime linkage can be found in the form of horizontal or vertical interplay (Young, 2002). Vertical one occurs, when two regimes of organizations standing at the different levels cross. The horizontal interactions happen at the same level of social organizations and for the purposes of this paper, the horizontal linkages represent the most important ones. To be more specific, the paper deals with the normative interplay that can be described as the situation, where the rules and regimes confirm or contradict the norms established by another institution and therefore affect their normative power and application. The categorization is certainly a useful tool that can be later used to analyze the question of the institutional interplay, but on the other hand, there can be severe doubts about the real outcomes of the theoretical distinction and its consequences for the empirically tested

3 The Green House Gases as subject of the Kyoto Protocol are carbon dioxide, methane, nitrous oxide and three groups of fluorinated gases (sulfur hexafluoride, HFCs, and PFCs). 
hypotheses. The paper will now describe the so called normative interplay in more details and try to elaborate the importance of its theoretical categorization.

The normative interplay as introduced above is one of the most suitable approaches to the relationship between trade end environmental regimes. The concept deals with the situation, occurred both deliberately or without any mutual awareness, where one international regime confirms or opposes the rules promoted by another regime and affect its normative power. The rules of any regime included in the normative interplay ought to be based on the so called international legitimacy (Franck, 1990, pp. 67-82). The rule has to fulfill the requirements of determinacy, understood as the fact that any vague statement indicates the disagreement among its creators and therefore makes it easier to justify the non-compliance. Another basic element of the regime rule is the coherence that refers to the consistency and capability of connectedness of the rule to other norms. The principle of procedural validation should be always respected as the rule that was not adopted according to the certain procedure completely lacks its legal power.

The existence of the regime linkages and its recognition is just the first step on the track to outline the consequences for the international governance and the efficient management of those institutional interactions. This paper will therefore deal with the question of the interplay management that can be defined as the deliberate effort of the participants in both regimes to prevent, encourage or shape the way, how one regime affects the solution of the problems under the other (Stokke, 2001, pp. 36-45). The interplay management can be found in the form of exchanging information between relevant participants, joint programs or the coordination of the decision making procedures. These examples represent the ideal state and are based on the assumption that the decision making bodies of the organizations representing the different regimes are willing to cooperate and find the most efficient solution of the problem. The model cases can lead to the conclusion that the regime interplay typically creates the incentives to manage the interactions in such a way as both organization enhance the joint gains and avoid the joint losses. The practical day to day operations of the regimes do not prove the model conclusions and there are evidences that the different actors seek to use the overlaps in a way to achieve their own goals. The interplay management is therefore more difficult and complex in reality and especially the case of the trade and the environment shows many significant conflicts of interests among the important actors in the affected fields.

\section{The regime interplay in practice - application of the theory}

The attempt to apply the theory of the regime interplay to the simplified case study has to begin with the statement of the basic assumptions of two different regime concepts. The first one could be defined as the climate change regime, represented by the programs, norms and rules under the United Nations Framework Convention on Climate Change and the Kyoto Protocol, dealing with the problems of global warming. The interactions between these two parts are understood as the processes within one regime without any significant outcomes for the second regime and its institutions. The second regime for our case study is the world trade regime, represented by the rules and programs adopted with several World Trade Organization Agreements and especially by its Dispute Settlement Mechanism with its binding jurisprudence. The WTO is hereinafter understood as the international organization as well as the international regime.

The relation between the world trade regime and the climate change is the typical example of the possible trade and environment conflict and therefore can be described as 
a typical case for the regime interplay. Their relation has to be viewed as the two-sided problem as the trade rules and the dispute settlement mechanism influence the agreements related to the climate change and the afford to avoid it, but the environmental rules found in several multilateral environmental agreements influence the trade regime as well, no matter if we recognize them as another kind of hidden trade restrictions or not. As mentioned above, this regime interplay is the case of the horizontal interplay, as the interactions appear between the organizations at the same social level. The most appropriate description of the nature of the interplay between the trade regime and the climate change rules is though the characteristic of the interplay as the normative one. The different regimes and the representing organizations have established the sets of norms that could confront or confirm each other with the significant consequences for both regimes ${ }^{4}$.

To continue in the case study, we have to analyze, how both regimes fulfill the requirements of the international legitimacy and its three basic elements as mentioned above. We have to answer the question, how they deal with the principles of determinacy, understood as the clarity of rules, coherence, understood as the ability to connect to other norms and the fulfillment of the procedural rules. The principle of determinacy is fully respected at the level of the world trade regime, where clear and enforceable rules of non-discrimination play the crucial role. The climate change regime is embodied in the general principle of reduction of the green house gases emissions under the United Nations Framework Convention and lately accompanied by the numerical reduction targets for some of the developed countries under the Kyoto Protocol. When we compare both regimes in regard to the connectedness to other norms, the world trade regime seems to be more developed. In the case of the regime conflicts, the WTO binding dispute settlement mechanism would be probably applied. The climate change regime is viewed as a potential source of conflict due to its important economic implications and the non-participation of important international subjects, especially the United States. The rules development of the world trade regime is significantly longer as its existence could be dated back to the 1940s and the principle of consensus is strictly followed. On the other hand, the climate change regime is relatively new one and however there is an internationally recognized goal of reducing the negative impacts of the climate change, the institutional adoption of the rules is more likely to be a source of conflict.

The comparative approach can lead us to the conclusion that the trade regime is more respectful to the requirements of the international legitimacy than the climate change one. It is especially due to its clear rules and the existence of the strict enforcement mechanism. It does not mean that the climate change regime is underdeveloped or not sufficient enough. Its legitimacy should not be evaluated as problematic one, particularly due to the short time that passed since its creation. The climate change regime faced the significant obstacles from the beginning, with the United States not adopting the Kyoto Protocol. The state of the world environmental made the attempt to combat the global warming the crucial goal of the international community and the drawbacks of its regime should not lessen its importance.

The different legitimacy, different use of regime interplay by some crucial actors and the comparative analyses of both regimes can explain why the conflicts occur and can even predict where the potential problems could arise. It does not answer the key question of the most suitable interplay management that could be able to contribute to the concrete solutions of the regime interplay problems. The comparative approach to the description of

4 The linkage between the climate change regime and the world trade regime could be also described as the functional interdependence as the adoption of the climate change rules can negatively influence the free movement of goods and related services. On the other hand the increase in the world trade in goods could lead, through the higher volume of transport, to the higher $\mathrm{CO}_{2}$ emissions and therefore negatively influence the climate change situation. 
both regimes could not be complete if we did not mention the alternative ways, how the international regimes could be dealt with. One of the alternative approaches is the analyses of the compatibility of them with the rules of general international law. The basic principles of general international law can be found in the Vienna Convention of the Law of Treaties (UN, 1969). Nevertheless, the Convention gives us only very limited juridical contribution to the solution of the question of the regime interplay. In respect to the lex posterior principle $^{5}$, the set of WTO agreements would have prevailed over the United Nations Framework Convention on Climate Change of 1992 due to its later adoption. On the other hand the Kyoto Protocol of 1997 would have precedence over the WTO agreements. If we try to apply the lex specialis principle ${ }^{6}$, different interpretations could be made. The environmental agreements, usually more general in nature, should be therefore prevailed by more specific WTO regime. On the other hand, the general climate change regime included in the United Nations Framework Convention is followed by many specific Multilateral Environmental Agreements and therefore, MEAs would prevail over more general WTO rules. The conclusion is that the Vienna Convention does not give us a suitable guidance for the solution of our case of the regime interplay.

\section{World Trade Organization - the typical kind of the international regime}

The description of the WTO is not the subject of this paper and just few basic remarks will be made. The international trade regime was created in 1947 when the General Agreement on Tariffs and Trade was adopted ${ }^{7}$ with the basic goal of the promotion of global economic development. The trade regime was based on two essential principles, the requirement to lower the tariffs and an obligation to eliminate other types of barriers to trade, so-called non-tariff barriers. From 1949 to 1994, eight negotiating took place with the Uruguay Round concluded in 1994, creating the World Trade Organization, where the decisions are made typically by consensus. The Ministerial Conference can be viewed as the major governing body, meeting at least once in two years with the authority to adopt any decision under the WTO agreements. Between the Ministerial Conference meetings, the General Council acts as the decision making body, being created by the senior representatives of all member states. Other bodies are represented by the Trade Policy Review Body, Committees, Working Groups and Working Parties. For our purposes, the Committee on Trade and Environment could be mentioned as the most important. One of the most significant outcomes of the Uruguay Round was the creation of the Dispute Settlement Mechanism as the binding dispute solution process. The mechanism can not force any state to chance its law, but the finding that the national rule contradicts the WTO trade regime means that the violating state can either negotiate compensations for the complaining side or can be subject to the trade sanctions.

5 The lex posterior principle could be found in the Article 30 of the Vienna Convention. It could be described as the rule that if all parties to an earlier treaty sign a new treaty, the common provisions of the two treaties will have precedence over the other provisions, but the uncommon provisions of the new one will remain in force. In addition, if the new treaty does not include all the original parties, the parties that have signed the new treaty are bound by it over the former treaty, but the parties that did not sign the new one remain bound by the original treaty.

6 The lex specialis principle means that in the event of a conflict between two agreements on the same subject matter, the more specific agreement should prevail over the more general one.

7 The General Agreement on Tariffs and Trade is an international Agreement that was first signed in 1948 by 23 countries and that established the internationally recognized trade regime. 
The crucial principle of the WTO lies in the non-discrimination rule that can be found in two fundamental principles of the international trade law. Article I of GATT established the Most-Favored Nation Rule, meaning that if special treatment is given to the goods or services from one country, they must be given to all WTO members. It has two major exceptions, the regional trade agreements and the developing countries. Article III of GATT established the National Treatment Rule, meaning that the goods of other countries ought to be treated the same way as similar products manufactured in the importing country. The term, similar products, has therefore many significant environmental implications. The general principle of the WTO trade regime, non-discrimination, does not have to be followed all the time. It could be exempted under circumstances mentioned in Article XX. of GATT. The environmental issues could be subsumed under these circumstances as well ${ }^{8}$. It is important to mention that the country trying to adopt such an exception has to prove its relevance under two justifications and the whole procedure is rather complicated.

In respect to the environment, the GATT did not represent an important player. Since 1995, when the WTO was established, the principle of sustainable development has become one of its objectives ${ }^{9}$. The environmental issues became a problematic agenda, bringing many obstacles to the progress of the further trade negotiations. It could be noticed at the failure of the Seattle Ministerial Conference in 1999, when the relations between trade and environment emerged as one of the major points of debate. The development of the debate about the trade and environment relation could be recently noticed on two different tracks. First is the political discussion within the Committee on Trade and Environment. This way is probably not going to lead to any significant progress due to the very difficult amendment procedure of the WTO Agreements. The second way is the WTO jurisprudence due to the adoption of environmentally relevant cases under its Dispute Settlement Mechanism. More in (Cihelková, 2007).

The standard type of the regime interplay could be found within the relations between WTO and Multilateral Environmental Agreemennts (MEAs). The concept of this paper does not allow us to describe the MEAs in more detailed way, but only few remarks have to be mentioned. Multilateral Environmental Agreements are voluntary treaties among sovereign countries that face environmental problems with global effects. They represent the key elements of the environmental governance and serve in a number of functions. They identify the cooperative solutions and therefore set up limits to the unilateral measures that could threaten the international trade regime. The other advantages are for instance the creation of a forum for assessing the state of the environment or the new framework that they establish for the negotiations of new environmental measures.

The complex nature of the measures established by different Multilateral Environmental Agreements could be described as well as another kind of the regime with all the features that were outlined above. The environmental regimes under certain MEAs vary in many ways, but they all respect some of the key principles that are embodied in the international environmental law (UNEP, 2000). Only few of them can be mentioned, such

8 Article XX. of GATT established the General Exception, which in respect to the environment, could be used in the form of the exceptions under letters $b$ and $g$. Exception $b$ allows to adopt the measures necessary to protect human, animal or plant life or health. Letter $g$ allows the same measures relating to the conservation of exhaustible natural resources.

9 As stated in the Marrakesh Agreement establishing the WTO. 
as the polluter pay principle or principles of prevention and precaution ${ }^{10}$. The growing number of MEAs may create certain problems in the multilateral environmental governance. The international environmental governance is shared by too many different actors and the competences are sometimes overlapping as well as the synergies are not fully employed. The environmental regimes also lack the binding dispute settlement mechanism that is an integral part of the WTO institutional structure. These could be recognized as the most relevant limitations to the more efficient use of MEAs as the part of the international environmental governance. If we try to find the linkage in between the WTO and MEAs, the most visible examples would probably be the dispute cases solved under the WTO jurisprudence ${ }^{11}$. The topic is evolving without any significant progress since 2001, when the negotiation mandate in Doha Ministerial Declaration was adopted with the specific statement about the relationship between the WTO and MEAs. The Doha Declaration stressed that the multilateral trading system and efforts towards environmental protection and sustainable development can and must be mutually supportive. The Doha negotiation mandate established the regular information exchange between the WTO and MEAs secretariats and open the way for granting several MEAs secretariats the WTO observer status. Nevertheless, the conclusions for the problem of different MEAs regimes and their compliance with the world trade regime under the WTO rules were very limited.

\section{The climate change regime}

The question of the climate change was getting on the agenda during the 1990s and it recently became one of the most complex environmental problems. The international climate change regime is based on two different international treaties and it makes one of the differences to the trade regime, which is carried on completely under the WTO agreements. First of them is the United Nations Convention on Climate Change (UNFCCC) of 1992 and the second one is the Kyoto Protocol of 1997. As stated above, the interactions between these two agreements are understood as the internal development within one regime. These treaties were preceded by the establishment of the Intergovernmental Panel on Climate Change in 1988, which was created with one simple aim, to prepare the first assessment of the potential risks of global warming. The first IPCC Report was published in 1990 concluding that the rising concentration of green house gases in the atmosphere was caused by human activities. The Report attracted much of the attention and the problem of the global warming became an economic and political issue. The public and scientific interests led to the negotiations on convention to break the trend of the global warming.

The UN Climate Change Convention was adopted during the UN Committee on Environment and Development Summit in Rio de Janeiro in 1992. The so-called climate convention protocol system was created on the model of successful Montreal Protocol on Substances that Deplete the Ozone Layer. The climate change regime is based on the key objective as stated in the Articles II and III of the UNCCC, the objective of stabilization of atmospheric concentration of green house gases at a level that would prevent dangerous interference with the climate system. The developed countries were determined to take the leading role in the fight against the climate change, but the concrete rules were not included. Only the soft rule of keeping the green house gases emissions of 2000 at the level

10 The other principles can be found in the Declaration on Environment and Development of 1992 adopted in Rio de Janeiro.

11 Among most often cited belong the Tuna I and Tuna II cases, the Turtle-Shrimp case, Reformulated Gasoline case and the Asbestos case. 
of 1990 was introduced, particularly due to the strong opposition of the United States towards any stricter binding rules. The institutional structure was also established with the Conference of the Parties as the major decision making body, meeting once a year and taking the decision by consensus. The Convention entered into force in March 1994, but the voluntary target did not represent the incentive for the countries to achieve its targets. In 1995, during the first Conference of the Parties in Berlin, the mandate for setting legally binding targets and timetable was adopted. The developing countries were guarantied to be excluded from any binding rules. The Berlin mandate led to the conclusion of the Kyoto Protocol at the third Conference of the Parties in December of 2007.

The Kyoto Protocol was the first document that established the legally binding targets for the emission reduction, differentiated for developed countries with the overall aim to achieve reduction at least 5\% compared to 1990 by 2008, respectively the period 2008-2012. The target for the member countries of the EU was rather ambitious with the reduction limit at $8 \%$. The Protocol has implemented a set of so called Kyoto mechanisms that are created to promote the reduction of the GHGs through international cooperation that allows to the participants to obtain the emission credits from other countries. There are several ways how to get them, for instance due to the emission trading system, joint implementation scheme or the clean development mechanism ${ }^{12}$. The basic problem of the Kyoto Protocol was that the major details of the several Kyoto mechanisms and the non-compliance regime were not stated in the Protocol as the common agreement was not achieved. The climate change regime is therefore, in respect to its enforcement, not legally binding. This fact stands in a severe contrast to the WTO trade system, as under the climate change regime there is no chance to begin with the retaliatory measures for non-compliers.

The general climate change regime is respected at the global level as the UNFCCC is ratified by almost all countries. The Kyoto Protocol is a different case with the United States not ratifying it, but participating in the negotiations. The Kyoto Protocol entered into force when Russia ratified it and fulfilled the requirement that countries accounting at least $55 \%$ of the emission of 1990 ratified the Protocol. The United States are party of the UNFCCC, but the Kyoto Protocol was understood as a potential danger for the US and world economy and was not adopted. On the other hand, United States participated in the negotiation and as one of the reasons announced that they want to secure that the undertaken measures would not infringe any other rights under the international regimes, including the WTO (US, 2001).

\section{The WTO and climate change regimes interplay}

First level that has to be analyzed is the normative interplay as described above. The question was if the rules of one regime confirm or oppose the rules of the other. One of their similarities is that norms of both regimes have their routes in the recognition of the need of the continuing process of their adoption as the problems they deal with, require the long-term approach. Even more significant similarity could be found in the common rejection of subsidies under norms of both regimes. The subsidies are viewed as a potential danger that could distort international trade and damage the environment and both regimes call for the reduction and phase out of them. If we compare both regimes, various

12 The emission trading system under Article 17 of Kyoto Protocol allows the developed countries to trade excess emission credits to other countries. The Joint Implementation Scheme under Article 6 is designed for the foreign investors and the host country to implement additional credits jointly. The Clean Development Mechanism, Article 12 , gives the opportunity to the developed countries to achieve additional emission credits by investing in emission reduction projects in the developing countries. 
differences appear within the normative interplay as well. One of them could be described as different general purposes of their existence. The norms under the climate change regime were adopted to correct the market failure and therefore, the basic economic tools how to achieve this remain in the hands of the national governments. The trade regime, with the aim to minimize the market distortions, tries to limit the range of economic tools available to the national governments. The norms of the climate change regime are determined to have any impact only if they are respected at the global level and the inter-governmental cooperation play a crucial role. On the other hand, the trade regime rules can be adopted at a different national speed without an important damage to the purposes of their existence. The problem of non-participants is also more serious for the climate change regime than for the trade one. Probably the most severe contrast between norms of both regimes is the different treatment of participating countries under the climate change regime, based on the level of their economic development and historical volume of the GHGs emissions. On the other hand, the basic principle of the WTO trade regime is the prohibition of any discrimination between countries. This stands as the most visible difference between the regime norms and rules.

Another level of the interplay analyses could be the existence of the trade measures under the climate change regime. Both UNFCCC and Kyoto Protocol do not enable to introduce any specific trade related environmental measures, but any concrete environmental measure could bring up the question of its conformity with the general trade rules. There is basically no possibility of participating countries to impose the trade measures on the non-compliers similar to the WTO regime. The potential trade measures as a respond on the non-compliance under the climate change regime would be probably considered as a national policy by the WTO. If the participants of any MEAs or existing Kyoto Protocol decide to forgo its WTO rights and enable the trade measures among them as a way how to enforce the binding environmental rules, it could be understood and respected among them without any consequences for the WTO regime. Nevertheless, the climate change ought to be faced at the global level with common approach ant therefore the trade measures could not be used as an effective tool due to the limited number of Kyoto participants and the problems with implementation of the potential trade measures against non-participating countries.

The climate change policies have a tremendous economic impact. The reduction limits on the emission could lead the lower fossil fuels demand with corresponding effects on their prices. The other effects are generally related to the competitiveness of the countries that would adopt severe environmental law. The fact that the United States do not participate on the Kyoto Protocol makes it more difficult to evaluate the economic implications of the recent establishment of binding emission limits. The limited content of this paper does not allow us to analyze the economic effects of both regimes and its consequences and we will now focus on the potential sources of conflicts between them.

The Kyoto Mechanisms as described above do not represent any compatibility problem with the WTO rules. The interesting fact is that the emission trading mechanism could be governed by the rules of GATS, as the secondary market in allowances derivates exists. The unclear question remains, how the national measures that are aimed to achieve the climate change regime targets could affect the international trade regime under WTO. The recent studies propose the strengthening of the cooperation between the two regimes for reducing the probability of conflict. The WTO has not yet connected the climate change problem to trade in a similar way as the other international organizations did. 


\section{Conclusion}

This paper tried to analyze the potential areas of conflicts between the world trade and climate change regime. The WTO system was characterized as quite progressive due to its jurisprudence under the Dispute Settlement Mechanism. On the other hand, the discussion within its Committee on Trade and Environment seems to be rather stagnating and even the Doha negotiation mandate on the WTO relationships to the Multilateral Environmental Agreements did not offer any incentive for any further significant development. Due to the binding nature of the WTO system, it could be assumed that in the case of conflict with the environmental regime, the world trade regime would prevail. As the climate change was analyzed, it was stated that it did not include any specific trade related measures and certain environmental measures would have to be evaluated individually. Especially the potential trade sanctions against the non-participating countries seem to bear severe risks. On the other hand, there are no signals yet, that the parties are not willing to avoid any conflicts by mutual negotiation rather than taking another country before the WTO dispute settlement.

It could be concluded that if a conflict between the WTO and climate change rules appears, the problematic situation would be represented by the dispute between the party and non-party country of the climate change regime treaty. The dispute would be probably settled by the WTO mechanism. The WTO rules prevent other regimes from using discriminatory measures against non-parties and therefore the WTO would protect the right of the non-party to arrange its environmental law according to its needs. Nevertheless, the dispute would enhance neither the climate change nor the world trade regime. The only efficient solution would be the common initiative to reduce the distorting measures as subsidies and the effort to find and use the regime synergies.

The theoretical approach, developed in the field of the regime interplay, provide a suitable framework for analyses of the relationship between the climate change and the world trade regime. On the other hand, the stress that it puts on the norms and institutions may lead to the underestimating of the political factors. Due to this fact, the outcomes may not respond to the reality in the most appropriate way. The recent studies that were focused basically on the comparison of the different regime norms are not sufficient enough. This paper attempted to avoid the limited approach and include into consideration wide range of factors.

\section{References}

CIHELKOVÁ, E. (2007). Postavení a spolupráce států ve Světové obchodní organizaci: obecný rámec. [The Position and the Cooperation of the States within the World Trade Organization: the General Framework.] Současná Evropa a Česká republika, No. 1, pp. 47-67.

EU (2000). Partnership Agreement between the members of the African, Caribbean and Pacific group of states of the one part, and the European Community and its member states, of the other part.

http://ec.europa.eu/development/ICenter/Pdf/agr01_en.pdf.

FRANCK, T. (1990). The power of legitimacy among nations. New York, Oxford, University Press. 
HOUSMAN, R.; GOLDBERG, D. (1995). Legal principles in resolving conflicts between MEAs and the GATT/WTO. In HOUSMAN, R., GOLDBERG, D. M., et al. (ed). The use of trade measures in select MEAs. Stockholm, UNEP.

HUFBAUER, G. (1994). US outward FDI promotes US Exports. http://www.sunsonline.org/trade/process/towards/09200294.htm.

KRASNER, S. (ed.), (1983). International Regimes. Ithaca and London, Cornwell University Press.

LIM, H. (1997). The Social Clause: Issues and Challenges. http://www.itcilo.it/english//actrav/telearn/global/ilo/guide/hoelim.htm.

OBERTHÜR, S. (2001). The international regime on climate change, in the context of the project "Institutional Interaction - How to prevent conflicts and enhance synergies between international and EU environmental institutions". Berlin, Ecologic.

OBERTHÜR, S.; GEHRING, T. (2003). Interaction between international and EU environmental institutions: conceptual foundations, in the context of the project "Institutional interaction". Berlin, Ecologic.

STOKKE, O. (2003). Trade measures, WTO, and climate compliance: the interplay of international regimes. Oslo, The Fridtjof Nansen Institute, FNI report 5/2003, Lysaker.

UN (1969). Vinna Convention on the Law of Treaties. http://untreaty.un.org/ilc/texts/instruments/english/conventions/1_1_1969.pdf.

UN (1992). United Nations Framework Convention on Climate Change. http://unfccc.int/resource/docs/convkp/conveng.pdf.

UNEP (2000). The Montreal Protocol on Substances that Deplete the Ozone Layer. http://www.unep.org/OZONE/pdfs/Montreal-Protocol2000.pdf.

US (2001). An analysis of the Kyoto Protocol-Climate Change Review: initial report. http://www.whitehouse.gov/news/releases/2001/06.

WOOD, A. (1996). Skill, Trade and International Inequality. http://www.ids.ac.uk/ids/bookshop/wp/WP47.pdf.

WTO (1947). General Agreement on Tariffs and Trade. http://www.wto.org/english/docs_e/legal_e/gatt47_e.pdf.

WTO (1994a). Marrakesh Declaration of 15 April 1994. http://www.g7.utoronto.ca/trade/marrakesh.html.

WTO (1994b). Understanding on Dispute Settlement. http://www.wto.org/english/tratop_e/dispu_e/dsu_e.htm.

WTO (1996a). Ministerial Declaration on Trade in Information Technology Products. http://www.wto.org/english/docs_e/legal_e/itadec_e.pdf.

WTO (1996b). Singapore WTO Ministerial 1996: Ministerial Declaration. wt/min(96)/dec, http://www.wto.org/english/thewto_e/minist_e/min96_e/wtodec_e.htm.

WTO (2006). The Evolving Debate on Trade and Labour Standards. http://www.wto.int/english/forums_e/ngo_e/posp63_ioe_e.pdf. 


\title{
Vzájemná souhra mezi mezinárodními režimy jako vztah mezi pravidly světového obchodu a životního prostředí
}

\begin{abstract}
Jakub Krč
Abstrakt

Existence světového obchodního režimu v rámci WTO a pravidel ochrany životního prostředí v rámci Rámcové konvence o klimatické změně a Kyotského protokolu může způsobit řadu problémů. Rozličné normy obou režimů se mohou vzájemně potvrzovat či si odporovat. $\mathrm{V}$ př́ípadě jejich nesouladu by byl pravděpodobně využit mechanismus urovnávání sporů v rámci WTO. Teorie vzájemného působení obou režimů poskytuje užitečné nástroje pro analýzu potenciálních oblastí konfliktů a může přispět k nalezení vhodného managementu obou systémů, který by plně využil jejich společných vlastností. Tato stat' se pokouší o nástin rozdílů mezi obchodními pravidly a režimem klimatické změny s důrazem na vzájemné překrývání jejich norem. Vychází z charakteristiky obou režimů a z jejich vzájemné analýzy s použitím nástrojů teorie tzv. regime interplay.
\end{abstract}

Klíčová slova: režim; souhra režimů; WTO; klimatická změna; Kyotský protokol.

\section{The Interplay between Multilateral Regimes as the Relationship between Trade and Environmental Rules}

\begin{abstract}
The existence of world trade regime under the WTO and the environmental regime under the UNFCCC and Kyoto Protocol can create several conflicts. The various norms of both regimes can confirm or contradict each other. In the case of a conflict, the Dispute Settlement Mechanism of the WTO is probably to be applied. The regime interplay theory offers suitable tools for analyses of potential areas of conflict and can lead to an adoption of an appropriate regime management that would enhance the regime synergies. This paper tries to outline the differences of the trade rules and climate change regime norms in regard to the overlaps of their norms. It is based on the characteristic of both regimes and on the regime interplay analyses applied on this model case of two international regimes.
\end{abstract}

Key words: regime; regime interplay; WTO; climate change; Kyoto Protocol.

JEL classification: K32, Q56 